\title{
Anterior Communicating Artery Complex Anatomy and its Correlation with Aneurysm Formation
}

\author{
MOHAMED SHADAD, M.D.; AHMED BALAHA, M.D. and AHMED GANNA, M.D. \\ The Department of Neurosurgery, Faculty of Medicine, Tanta University
}

\begin{abstract}
Background: The anterior communicating artery (ACoA) is considered the most common site for intracranial aneurysms. The relation between the aneurysm formation and the ACoA complex anatomy is poorly described although it may be one of the most affecting factors in aneurysm incidence.

Aim of Study: The aim of this study is to find the correlation between the anatomical variations of the ACoA and development of ACoA aneurysms, and also to analyze the angiographic differences between them.

Patients and Methods: The study group consists of 40 patients diagnosed with ACoA aneurysm and the control group consists of 70 persons, using conventional cerebral angiography.

Results: A strong co-relation was found within the study group between the occurrence of ACoA aneurysm and hypoplastic A1 segment of the anterior cerebral artery versus the control group ( $25 \%$ vs. $7.14 \%$ ), also there is also a high incidence of aplastic A1 segment of the anterior cerebral artery versus the control group (12.5\% vs. $2.86 \%)$.

Conclusion: ACoA aneurysm formation is more common with hypoplasia or aplasia of the A1 segment of the anterior cerebral artery.
\end{abstract}

Key Words: Anterior cerebral artery - Anterior communicating artery aneurysm - Anatomical variations - Anterior communicating artery complex - Cerebral angiography.

\section{Introduction}

INTRACRANIAL vascular variations are common findings in the general population. Knowledge of the vascular variations has an important clinical effect as some of them arry the risk for development of aneurysms [10]

The most common site of the intracranial aneurysms is the anterior communicating artery (ACoA). Multiple anomalies such as hypoplasia, aplasia, or

Correspondence to: Dr. Mohamed Shadad, The Department of Neurosurgery, Faculty of Medicine, Tanta University duplication of the ACoA have been described [12] Anatomical variations in the ACoA complex promotes stronger hemodynamic changes and therefore endorses the formation of an intracranial aneurysm [17].

The anterior communicating artery complex is composed of two anterior cerebral arteries (ACA), the anterior communicating artery $(\mathrm{ACoA})$ and the recurrent arteries of Heubner. ACA is divided into five segments; A1 origins from the internal carotid artery to the ACoA, A2 starting from ACoA to the origin of calloso-marginal artery vertically, A3 distal to the origin of calloso-marginal, A4 above the body of corpus callosum, and A5 posterior to the coronal suture [9]

Based on the anatomical and radiological studies, less than $50 \%$ of the general population has complete Circle of Willis. Studies showed that there's a great importance of the flow-dependent alterations in the formation and development of the ACoA aneurysm [4].

One of the mechanisms for aneurysm development is the asymmetric flow of blood in the vessels as it causes severe hemodynamic stress on the arterial walls [15]. Arterial wall sheer stress causes activation of several molecular mechanisms including nitric oxide synthase and apoptosis of arterial wall smooth muscle cells leading to aneurysmal formation and development [19]

Many studies found that A1 ACA segment anomalies as the most common variant accompanying ACoA aneurysm. There are several methods to diagnose the ACoA aneurysm and to identify the anatomical variations in ACoA complex such as CT Brain Angiography, Brain MRA, Cerebral Angiography, and intraoperative observations [18] 
The commonest presentation of ACoA aneurysms is the clinical manifestations related to ruptured aneurysms in the form of subarachnoid hemorrhage or intracerebral hematoma. It may also be discovered accidentally on investigating patients with persistent headache or during angiographic studies for other intracranial pathologies [6].

Our study aims to find the correlation between the anatomical variations of the ACoA and development of ACoA aneurysms, and also to analyze the angiographic differences between them.

\section{Patients and Methods}

This study was retrospectively carried on in Tanta University Hospitals. We studied the radiological findings in patients who underwent conventional cerebral angiography during the period from January 2015 to January 2020 . The participants were divided into 2 groups; the study group and the control group. All participants were enrolled for angiographic study of their cerebrovascular anatomy after signing an informed consent for the purpose of the investigations.

The study group (Group 1) consisted of 40 patients who were diagnosed radiologically with either ruptured or unruptured ACoA aneurysm.

The control group (Group 2) consisted of 70 patients who underwent angiographic study for any indication such as persistent headache or traumatic subarachnoid hemorrhage and their study revealed no cerebrovascular anomalies such as aneurysms or arteriovenous malformations.

The researchers examined all parts of the ACoA complex for any possible anomalies. Arterial hypoplasia is considered when the internal diameter of the artery is less than $50 \%$ of the diameter of the contralateral artery.

The researchers classified the possible ACoA complex variations into the following: typical configuration, ACoA hypoplasia, ACoA aplasia, unilateral hypoplasia of A 1 ACA segment, unilateral aplasia of the A1 ACA segment, common trunk of ACA with absence of ACoA, presence of a third A2 ACA segment (median artery of corpus callosum), unilateral hypoplasia of both A1 and A2 ACA segments, unilateral aplasia of A2 ACA segment, unilateral hypoplasia of A2 ACA segment, and duplicated ACoA.

\section{Results}

The study group consisted of 25 females and 15 males with a mean age of $54.48 \pm 8.92$ years. The control group consisted of 42 females and 28 with a mean age of $47.99 \pm 13.53$ years (Table 1 ).

Regarding the study group; 23 patients $(57.5 \%)$ had typical configuration, 10 patients $(25 \%)$ had unilateral A1 ACA segment hypoplasia, 5 patients $(12.5 \%)$ had unilateral A1 ACA segment aplasia, 1 patient $(2.5 \%)$ had unilateral hypoplasia of both A1 and A2 ACA segments, and 1 patient $(2.5 \%)$ had unilateral A2 ACA segment aplasia (Azygos ACA) (Table 2). Examples of the radiological findings are illustrated in Figs. (1-3).

Regarding the control group; 49 patients (70\%) had typical configuration, 10 patients $(14.29 \%)$ had ACoA aplasia, 5 patients (7.14\%) had unilateral A1 ACA segment hypoplasia, 2 patients (2.86\%) had unilateral A1 ACA segment aplasia, 3 patients (4.29\%) had common trunk of ACA with absence of ACoA and 1 patient (1.43\%) had unilateral A2 ACA segment aplasia (Azygos ACA) (Table 2).

We noticed a statistical association between unilateral A1 ACA segment hypoplasia and ACoA aneurysm formation in the study group versus the control group ( $25 \%$ vs. $7.14 \%)(p=0.020)$. Also, there's a statistical association between unilateral A1 ACA segment aplasia and ACoA aneurysms in the study group versus the control group $(12.5 \%$ vs. $2.86 \%)(p=0.041)$. Statistically, there was no association between A2 ACA segment hypoplasia or aplasia and ACoA aneurysms (Table 2).

Regarding the relations between the anatomical variations of ACoA complex and the gender in both groups, there's no statistical significance between the sex and the anatomical variations (Tables 3,4).

Table (1): Patients characteristics according to age in both groups.

\begin{tabular}{llclll}
\hline & \multicolumn{2}{c}{ Age } & & \multicolumn{2}{c}{$t$-test } \\
\cline { 2 - 3 } \cline { 5 - 6 } Groups & Range & Mean $\pm \mathrm{SD}$ & & $t$ & $p$-value \\
\hline Group I & $42-70 \mathrm{y}$ & $54.48 \pm 8.92$ & & 2.712 & $0.008^{*}$ \\
Group II & $25-70 \mathrm{y}$ & $47.99 \pm 13.53$ & & \\
\hline
\end{tabular}


Table (2): The statistical analysis of the anatomical variations of ACoA complex in both groups.

\begin{tabular}{|c|c|c|c|c|c|c|c|c|}
\hline \multirow{3}{*}{ Type } & \multicolumn{6}{|c|}{ Groups } & \multirow{2}{*}{\multicolumn{2}{|c|}{ Chi-square }} \\
\hline & \multicolumn{2}{|c|}{$\begin{array}{l}\text { Group I } \\
(n=40)\end{array}$} & \multicolumn{2}{|c|}{$\begin{array}{l}\text { Group II } \\
(\mathrm{n}=70)\end{array}$} & \multicolumn{2}{|c|}{$\begin{array}{c}\text { Total } \\
(\mathrm{n}=110)\end{array}$} & & \\
\hline & $\mathrm{N}$ & $\%$ & $\mathrm{~N}$ & $\%$ & $\mathrm{~N}$ & $\%$ & $X^{2}$ & $p$-value \\
\hline Typical configuration & 23 & 57.50 & 49 & 70.00 & 72 & 65.45 & 9.389 & $0.002 *$ \\
\hline Hypoplastic ACoA & 0 & 0.00 & 0 & 0.00 & 0 & 0.00 & & \\
\hline Aplastic ACoA & 0 & 0.00 & 10 & 14.29 & 10 & 9.09 & 4.676 & $0.031 *$ \\
\hline Unilateral A1 hypoplasia & 10 & 25.00 & 5 & 7.14 & 15 & 13.64 & 5.459 & $0.020 *$ \\
\hline Unilateral A1 aplasia & 5 & 12.50 & 2 & 2.86 & 7 & 6.36 & 2.519 & $0.041 *$ \\
\hline Common trunk of ACA with absence of ACoA & 0 & 0.00 & 3 & 4.29 & 3 & 2.73 & 0.517 & 0.472 \\
\hline Presence of a third A2 & 0 & 0.00 & 0 & 0.00 & 0 & 0.00 & & \\
\hline Unilateral hypoplasia of both A1 and A2 & 1 & 2.50 & 0 & 0.00 & 1 & 0.91 & 0.081 & 0.776 \\
\hline Unilateral A2 aplasia & 1 & 2.50 & 1 & 1.43 & 2 & 1.82 & 0.000 & 1.000 \\
\hline Unilateral A2 hypoplasia & 0 & 0.00 & 0 & 0.00 & 0 & 0.00 & - & - \\
\hline Duplicated ACoA & 0 & 0.00 & 0 & 0.00 & 0 & 0.00 & - & - \\
\hline Total & 40 & 100.00 & 70 & 100.00 & 110 & 100.00 & - & - \\
\hline
\end{tabular}

Table (3): The relationship between the anatomical variants of ACoA complex and the gender in group $1(n=40)$.

\begin{tabular}{|c|c|c|c|c|c|c|c|c|}
\hline \multirow{3}{*}{ Type group I } & \multicolumn{6}{|c|}{ Sex } & & \\
\hline & \multicolumn{2}{|c|}{ Male } & \multicolumn{2}{|c|}{ Female } & \multicolumn{2}{|c|}{$\begin{array}{c}\text { Total } \\
(\mathrm{n}=70)\end{array}$} & \multicolumn{2}{|c|}{ Chi-square } \\
\hline & $\mathrm{N}$ & $\%$ & $\mathrm{~N}$ & $\%$ & $\mathrm{~N}$ & $\%$ & $\mathrm{X}^{2}$ & $p$-value \\
\hline Typical configuration & 8 & 53.33 & 15 & 60.00 & 23 & 57.50 & 0.007 & 0.934 \\
\hline Unilateral A1 hypoplasia & 4 & 26.67 & 6 & 24.00 & 10 & 25.00 & 0.036 & 0.850 \\
\hline Unilateral A1 aplasia & 2 & 13.33 & 3 & 12.00 & 5 & 12.50 & 0.137 & 0.711 \\
\hline Unilateral hypoplasia of both A1 and A2 & 1 & 6.67 & 0 & 0.00 & 1 & 2.50 & 0.068 & 0.794 \\
\hline Unilateral A2 aplasia & 0 & 0.00 & 1 & 4.00 & 1 & 2.50 & 0.068 & 0.794 \\
\hline Total & 15 & 100.00 & 25 & 100.00 & 40 & 100.00 & - & - \\
\hline
\end{tabular}

Table (4): The relationship between the anatomical variants of ACoA complex and the gender in group $2(n=70)$.

\begin{tabular}{|c|c|c|c|c|c|c|c|c|}
\hline \multirow{3}{*}{ Type group II } & \multicolumn{6}{|c|}{ Sex } & & \\
\hline & \multicolumn{2}{|c|}{ Male } & \multicolumn{2}{|c|}{ Female } & \multicolumn{2}{|c|}{$\begin{array}{l}\text { Total } \\
(\mathrm{n}=70)\end{array}$} & \multicolumn{2}{|c|}{ Chi-square } \\
\hline & $\mathrm{N}$ & $\%$ & $\mathrm{~N}$ & $\%$ & $\mathrm{~N}$ & $\%$ & $x^{2}$ & $p$-value \\
\hline Typical configuration & 19 & 69.15 & 30 & 71.43 & 49 & 70.00 & 0.003 & 0.958 \\
\hline Aplastic ACoA & 4 & 13.00 & 6 & 15.09 & 10 & 14.29 & 0.122 & 0.727 \\
\hline Unilateral A1 hypoplasia & 2 & 7.14 & 3 & 7.30 & 5 & 7.14 & 0.224 & 0.636 \\
\hline Unilateral A1 aplasia & 1 & 3.57 & 1 & 2.30 & 2 & 2.86 & 0.193 & 0.660 \\
\hline $\begin{array}{l}\text { Common trunk of ACA with } \\
\text { absence of ACoA }\end{array}$ & 2 & 7.14 & 1 & 2.30 & 3 & 4.29 & 0.131 & 0.718 \\
\hline Unilateral A2 aplasia & 0 & 0.00 & 1 & 2.30 & 1 & 1.43 & 0.042 & 0.837 \\
\hline Total & 28 & 100.00 & 42 & 100.00 & 70 & 100.00 & - & - \\
\hline
\end{tabular}



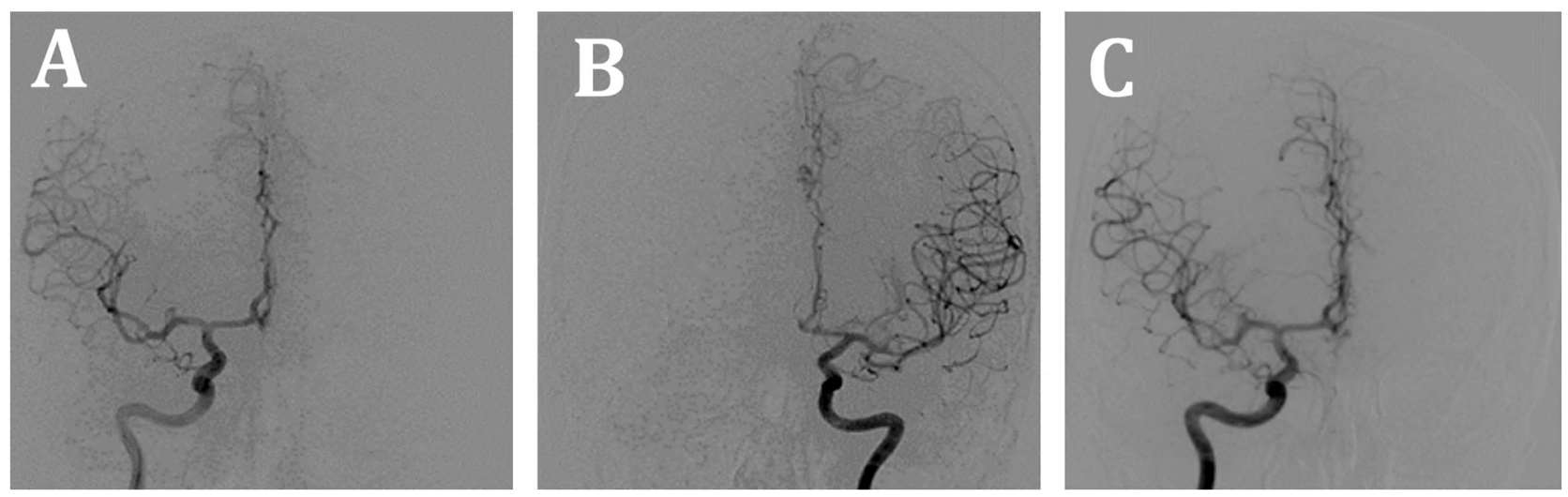

Fig. (1): A male patient aged 43 years old presented with severe headache due to SAH. Angiographic study revealed ACoA aneurysm with cross dominance of A1 on both sides (A) Right \& (B) Left, (C) Total obliteration of the aneurysm.
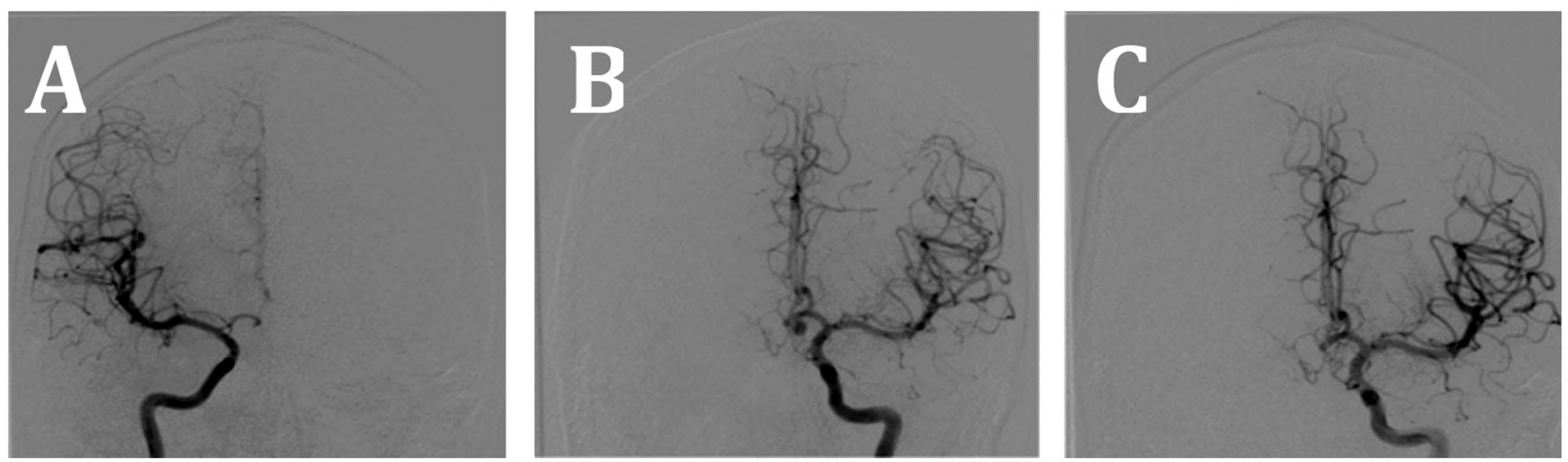

Fig. (2): A male patient aged 42 years old, presented with severe headache and disturbed conscious level GCS 14 due to SAH. Angiographic study revealed ACoA aneurysm with hypoplastic A1 segment on right side (A) and dominant A1 on left side (B), (C) Total obliteration of the aneurysm.
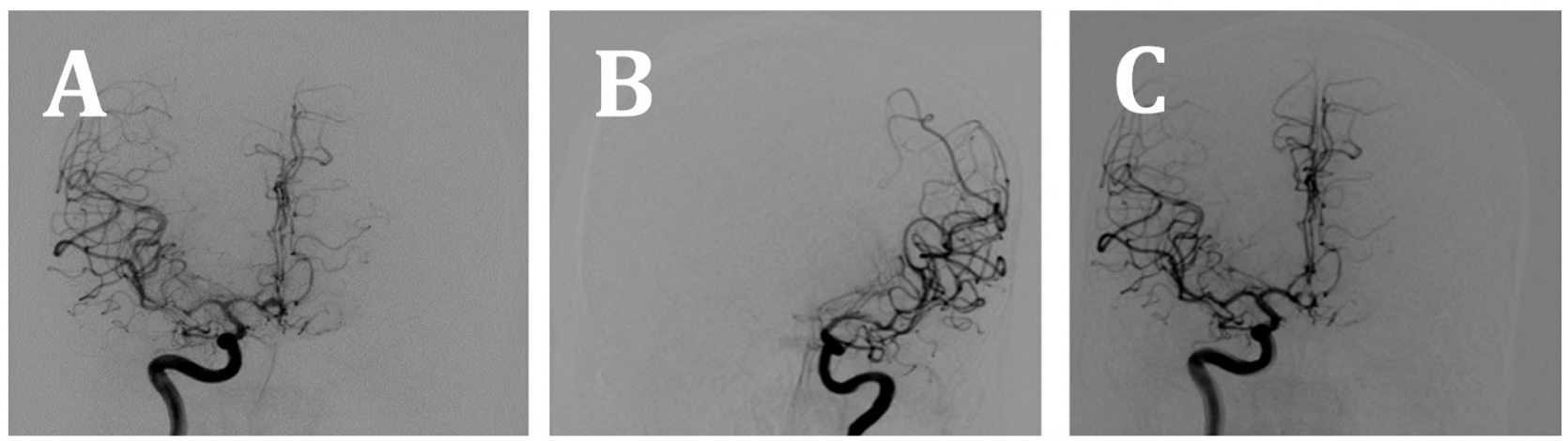

Fig. (3): A female patient aged 50 years old presented with sudden acute headache due to SAH. Angiographic study revealed ACoA aneurysm with aplastic A1 segment on left side (B) with dominant A1 on right side (A), (C) total obliteration of the aneurysm.

\section{Discussion}

The aim of this study was to find the correlation between the anatomical variations of ACoA complex and aneurysms formation.

In our study, we used both DSA and CT angiography to study the ACoA complex and to detect different anatomical variations. The use of both modalities (CTA \& DSA) gives more accurate results and more identification of the anatomical variants and ACoA aneurysms.
We found in the control group in our study that the typical configuration of the ACoA complex represents $70 \%$ of cases, while the most common anatomical atypical variations were aplastic ACoA in $14.29 \%$, followed by unilateral A 1 ACA segment hypoplasia in $7.14 \%$ of cases. This coincides with results of other publications which had found typical configuration in 53-80\%, unilateral A1 ACA segment hypoplasia in 7\%, and aplastic ACoA in $7-19 \%$ of populations without any intracranial pathologies $[11,16]$ 
In patients with ACoA aneurysm (the study group), we have found that the most common anatomical variant was unilateral A 1 ACA segment hypoplasia in $25 \%$ of the patients. In the literature, the incidence of unilateral A1 ACA hypoplasia ranges from $11-24 \%$ of patients with ACoA aneurysms $[1,3,8,9]$.

Our study group showed that the second most common anatomical variant was unilateral A1 ACA segment aplasia in $12.5 \%$ of patients. In the literature, the incidence ranges from 12 to $33 \%$ [1,3,8,9]

So according to the literature, the most common anatomical variants that are associated with $\mathrm{ACoA}$ aneurysm are the hypoplasia or aplasia of A1 ACA segment. The main factor is the effect of hemodynamic alterations across the Circle of Willis and the asymmetric A1 segment blood inflow $[2,14]$.

Despite several studies done before, the exact pathophysiology of aneurysms remains unclear. It seems that mechanical stress on the arterial wall may play the main role [13]. It was described that the site of arterial branching is a common site for aneurysmal development where's the wall stress is at its maximum [5].

Although the theory of mechanical stress could explain common sites of aneurysm formation mainly in cases of disturbed blood flow, it could not fully explain other cases of aneurysm formation. Another possible explanation of aneurysmal development is the remodeling process of the vascular extracellular matrix. Angiogenetic factors such as vascular endothelial growth factor (VEGF), Nitric oxide (NO), and Matrix metalloproteinases (MMPs) were found at higher levels in the aneurysmal wall than the normal arterial wall. These factors make the aneurysmal wall a dynamic structure that renews rapidly, leading to aneurysmal wall weakening, further growth and subsequent rupture [7]

This theory could provide an explanation for the development of ACoA aneurysms in most of patients that the angiographic studies revealed no associated vascular abnormalities. In our study, $57.5 \%$ of patients with ACoA aneurysms have typical configuration.

\section{Conclusion:}

We concluded that the risk of ACoA aneurysm development is significantly higher in patients with A1 ACA segment hypoplasia or aplasia.

\section{References}

1- AGAYEV K., ÖNAL B., YAVUZ K. and ZiYAL M.I.: The association of A1 segment hypoplasia/aplasia with anterior communicating artery aneurysms: A radiological study. Turkish Neurosurgery, 15 (4): 196-199, 2005.

2- CASTRO M.A., PUTMAN C.M., SHERIDAN M.J. and CEBRAL J.R.: Hemodynamic Patterns of Anterior Communicating Artery Aneurysms: A Possible Association with Rupture. American Journal of Neuroradiology, 30 (2): 297-302, 2009

3- CHARBEL F.T., SEYFRIED D., MEHTA B., DUJOVNY M. and AUSMAN J.I.: Dominant Al: Angiographic and clinical correlations with anterior communicating artery aneurysms. Neurological Research, 13 (4): 253-256, 1991.

4- FATTAHIAN R., GORJI R.A., SADEGHI M. and BAGHERI S.R.: Assessment of the Prevalence of Vascular Anomalies of the Circle of Willis Based on the Autopsy of Cadavers in Kurdish Race Between 2016 and 2017. Materia Socio-medica, 30 (3): 189, 2018.

5- HOI Y., MENG H., WOODWARD S.H., BENDOK B.R., HANEL R.A., GUTERMAN L.R., et al.: Effects of arterial geometry on aneurysm growth: Three-dimensional computational fluid dynamics study, 101 (4): 676, 2004.

6- JUVELA S.: Treatment Scoring of Unruptured Intracranial Aneurysms. Stroke, 50 (9): 2344-2350, 2019.

7- KARAZINCIR S., ADA E., SARSILMAZ A., YALÇIN O., VIDINLI B. and SAHIN E.: [Frequency of vascular variations and anomalies accompanying intracranial aneurysms]. Tani Girisim Radyol., 10 (2): 103-109, 2004.

8- KASUYA H., SHIMIZU T., NAKAYA K., SASAHARA A., HORI T. and TAKAKURA K.: Angles between A1 and $\mathrm{A} 2$ segments of the anterior cerebral artery visualized by three-dimensional computed tomographic angiography and association of anterior communicating artery aneurysms. Neurosurgery, 45 (1): 89-94, 1999.

9- KLIMEK-PIOTROWSKA W., KRZYŻEWSKI R.M., URBANIK A., TOMASZEWSKA I.M., LORENC N., KOCHANA M., et al.: Variations of the anterior communicating artery complex and occurrence of anterior communicating artery aneurysm: A2 segment consideration. Folia medica Cracoviensia, 2014

10- KOVAC J.D. STANKOVICA., STANKOVIC D., KOV AC B. and SARANOVIC' D.: Intracranial art erial variations: A comprehensive evaluation using CT angiography. Medical science monitor: International medical journal of experimental and clinical research, 20: 420, 2014.

11- KRASNY A., NENSA F., SANDALCIOGLU I., GÖRICKE S., WANKE I., GRAMSCH C., et al.: Association of aneurysms and variation of the A1 segment. Journal of NeuroInterventional Surgery, 6 (3): 178-183, 2014.

12- KRZYŻEWSKI R.M., TOMASZEWSKI K.A., KOCHANA M., KOPEC'M., KLIMEK-PIOTROWSKA W. and WALOCHA J.A.: Anatomical variations of the anterior communicating artery complex: Gender relationship. Surgical and Radiologic Anatomy, 37 (1): 81-86, 2015.

13- KWAK R., NIIZUMA H. and SUZUKI J.: Hemodynamics in the Anterior Part of the Circle of Willis in Patients with Intracranial Aneurysms: A Study by Cerebral Angiography. 
The Tohoku Journal of Experimental Medicine, 132 (1): 69-73, 1980.

14- LIU Z., CAI Y., GUO-ZHONG C., LU G-M. and LI Z$\mathrm{Y}$.: Anatomical variations in circle of willis and intracranial aneurysm formation. Molecular \& Cellular Biomechanics, 14 (1): 19, 2017.

15- PENN D.L., KOMOTAR R.J. and SANDER CONNOLLY E.: Hemodynamic mechanisms underlying cerebral aneurysm pathogenesis. Journal of Clinical Neuroscience, 18 (11): 1435-1438, 2011.

16- POLAK J., CIUK S., KUCYBALA I., GILIAVAS J. GAJDOSZ A. and URBANIK A.: Cerebral Aneurysms: Are They Associated with Anatomic Variations of Carotid and Main Cerebral Arteries? World Neurosurgery, 124: e604-e608, 2019.

17- SAVASTANO L.E., BHAMBRI A., WILKINSON D.A. and PANDEY A.S.: Biology of cerebral aneurysm formation, growth, and rupture. Intracranial Aneurysms: Elsevier, p. 17-32, 2018.

18- Y1LMAZ A. and ÖZKUL A.: Anatomical variations of anterior circulation in the brains of patients with and without intracranial aneurysm. Turkish Journal of Cerebrovascular Diseases, 24 (1): 8-13, 2018.

19-ZHOU G., ZHU Y., YIN Y., SU M. and LI M.: Association of wall shear stress with intracranial aneurysm rupture: Systematic review and meta-analysis. Scientific Reports, 7 (1): 1-8, 2017.

\section{تشريح مجموعة الشريان الموصل المخىى الأمامى الهمدئ

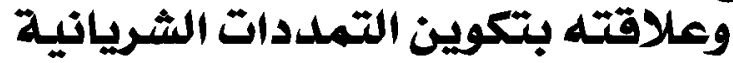

الخلفية: يعتبر الشريان الموصل الأمامى الموقع الاكثر ثيوعاً لصلوث تمدد الأوعية الدموية داخل الجمجمة. تم وصف العلاقة بين تكوين

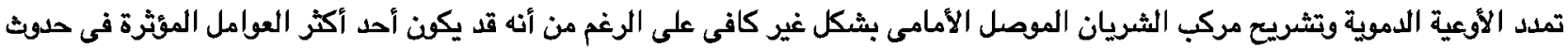
تمدد الأوعية الدموية.

الهدف من هذه الدراسـة: هو إيجاد العلا قة بين الاختلافات التشريصية للشريان الموصل الأمامى وتطور تمدد الأوعية الدموية، وكذلك

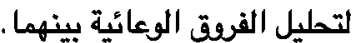

المرضى والطرق: تتكفن مجموعة الدراسة من · ع مريضاً تم تشخيصهم بوجود تمدد شريانى فى الثريان الموصل الأمامى، وتتكن

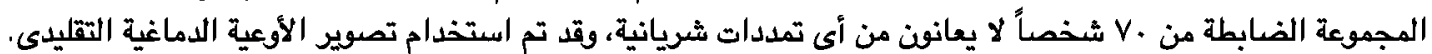

النتائج: تم العثود على علا قة قوية داخل مجموعة الدراسة بين حدوث ثمدد بالشريان الموصل الأمامى ووجود نقص بالنموفى الجزء الأول

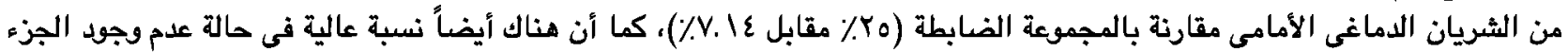

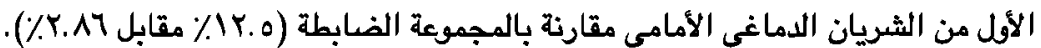

الخلاصة: تكن احتمالية حدوث التمدد بالشريان الموصل الأمامى أكثر في حالات نقص النمو أو عدم وجود الجزء الأول من الشريان 